\title{
ANALISIS KEMAMPUAN KOMUNIKASI MATEMATIS PADA PEMBELAJARAN MATEMATIKA REALISTIK
}

\author{
BENEDIKTA EDA LABINA ${ }^{1}$, BERNADUS BIN FRANS RESI ${ }^{2}$ \\ ${ }^{1}$ Pendidikan Matematika Instutut Keguruan dan Teknologi Larantuka, Nusa Tenggara Timur \\ chellnzakellen@gmail.com \\ ${ }^{2}$ Pendidikan Matematika Instutut Keguruan dan Teknologi Larantuka, Nusa Tenggara Timur \\ bernadusbinfrans.resi@gmail.com
}

First Received: 12-10-2020; Accepted: 26-10-2020

\begin{abstract}
Abstrak
Penelitian ini bertujuan untuk mengetahui kemampuan komunikasi matematis siswa kelas X MIA SMAK St. Fransiskus Asisi Larantuka pada topik persamaan nilai mutlak linear satu variabel menggunakan pendekatan matematika realistik. Jenis penelitian yang digunakan adalah kualitatif. Subjek penelitian adalah 2 orang siswa. Pemilihan subjek penelitian berdasarkan kategori jawaban siswa dengan ketentuan jawaban yang sejenis dikelompokkan kemudian dipilih salah seorang siswa sebagai subjek penelitian. Metode pengumpulan data berupa tes tertulis mengenai masalah kontekstual yang berkaitan dengan persamaan nilai mutlak linear satu variabel dan wawancara tidak struktur untuk mengetahui kemampuan komunikasi matematis siswa. Teknik analisis data menggunakan reduksi data, penyajian data, dan verifikasi data atau kesimpulan. Hasil penelitian menunjukkan bahwa siswa kelas X MIA SMAK St. Fransiskus Asisi Larantuka sudah memiliki kemampuan komunikasi matematis dengan baik. Siswa sudah mampu menyatakan situasi, gambar, diagram atau benda nyata ke dalam bahasa simbol, ide, atau model matematika, menjelaskan suatu ide, situasi atau relasi matematika melalui gambar, menyajikan solusi dari persamaan matematika secara rinci dan benar, memeriksa kembali jawaban siswa.
\end{abstract}

Kata kunci: Pendekatan Matematika Realistik; kemampuan komunikasi matematis; persamaan nilai mutlak linear satu variabel

\section{ANALYSIS OF MATEMATIC COMMUNICATION SKILLS ON REALISTIC MATHEMATICS LEARNING}

\begin{abstract}
This study aims to determine the mathematical communication skills of class X MIA SMAK St. students. Fransiskus Asisi Larantuka on the topic of equations of the absolute linear value of one variable using a realistic mathematical approach. This research was conducted in October 2019. The type of research used was qualitative. The research subjects were 3 students, however, in this paper only 2 students were discussed. Selection of research subjects based on the category of student answers provided that similar answers are grouped and then one student is selected as the research subject. The data collection method is in the form of a written test on contextual problems related to the equation of the absolute linear value of one variable and unstructured interviews to determine students' mathematical
\end{abstract}


communication skills. Data analysis techniques used data reduction, data presentation, and data verification or conclusions. The results showed that the students of class X MIA SMAK St. Fransiskus Asisi Larantuka, already has good mathematical communication skills. Students are able to express real situations, pictures, diagrams or objects into the language of symbols, ideas, or mathematical models, explain an idea, situation or mathematical relation through pictures, present solutions of mathematical equations in detail and correctly, check students' answers.

Keywords: Realistic mathematic education; mathematical communication skills; absolute value equation in one variable

\section{PENDAHULUAN}

Matematika merupakan salah satu pelajaran yang dipelajari di setiap jenjang pendidikan. Tidak dapat dipungkiri bahwa sebagian besar siswa menganggap bahwa matematika adalah pelajaran yang sulit dan membosankan. Berdasarkan wawancara yang dilakukan, guru mengatakan bahwa kemampuan siswa dalam menyelesaikan soal cerita masih lemah. Salah satu kesulitan yang dialami siswa adalah siswa mengalami kesulitan dalam memodelkan soal cerita ke dalam model matematika. Guru juga mengatakan bahwa, metode yang digunakan dalam pembelajaran adalah metode ceramah. Oleh karena itu siswa berperan pasif, sedangkan guru yang aktif. Hal ini menyebabkan siswa merasa jenuh dengan pelajaran matematika. Pembelajaran matematika secara konvensional juga sudah tidak relevan dengan pembelajaran saat ini, siswa cenderung menghafal materi yang disampaikan oleh guru tanpa memahami (Suprihatiningsih dkk, 2020). Beberapa siswa mengatakan bahwa mereka mengalami kesulitan dalam menylesaikan soal kontekstual karena guru jarang memberikan soal cerita kepada siswa.

Dalam pembelajaran matematika, sebaliknya guru memilih pendekatan pembelajaran yang sesuai, agar siswa tidak merasa bosan dengan matematika. Salah satu pendekatan pembelajaran yang dianggap sesuai yang dapat melatih kemampuan komunikasi matematis siswa adalah pendekatan matematika realistik (PMR). Pendekatan matematika realistik merupakan pembelajaran yang berkaitan dengan masalah kontekstual dalam kehidupan seharihari. Pada pembelajaran ini siswa lebih berperan aktif daripada guru, sehingga siswa diberikan kesempatan untuk menemukan sendiri solusi dari permasalahan yang diberikan. Guru hanya sebagai pendamping atau fasilitator. Realistic Mathematics Education (RME) merupakan salah satu pendekatan pembelajaran yang diawali dengan masalah nyata yang dihadapi siswa dalam kehidupan sehari-hari. Hans Freudenthal menyatakan dalam RME matematika dianggap sebagai aktivitas insani (mathematics as human activites) dan harus berkaitan dengan realita. Di dalam RME pembelajaran harus dimulai dari sesuatu yang nyata sehingga siswa dapat 
terlibat dalam proses pembelajaran secara bermakna. Dalam proses pembelajaran, peran guru hanya sebatas pembimbing atau fasilitator bagi siswa dalam proses rekonstruksi ide dan konsep matematika (Resi, 2018).

Menurut Gravemeijer (dalam Resi \& Hongki, 2018: 238), pembelajaran matematika dengan pendekatan RME memiliki 5 krakteristik, yaitu (1) Phenomenological exploratio, pembelajaran dimulai dari masalah nyata yang dekat dengan siswa atau sering dijumpai oleh siswa dalam kehidupan sehari-hari. Tujuannya siswa dapat mengontruksi masalah tersebut ke dalam model matematika dan menyelesaikannya; (2) Bridging by vertical instrument, berangkat dari masalah kontekstual siswa menggunakan srategi pemecahan masalah untuk merepresentasikan dalam bentuk model matematika. Model matematika berupa simbol matematika, skema, grafik, maupun diagram. Model tersebut digunakan siswa sebagai jembatan untuk mengantarkan siswa dari matematika informal (matematisasi horizontal) ke matematika formal (matematisasi vertikal); (3) Student contrabution, siswa sendiri menggunakan produksi dan kontruksi model. Oleh karena itu, diharapkan siswa mampu mengontruksi masalah kontekstual ke model formal. Siswa berperan aktif dalam mengontruksi sendiri pengetahuannya, sedangkan guru sebatas fasilitator atau pendamping; (4) Interactivity, adanya interaksi diantara siswa dalam proses pembelajaran. Bentuk interaksi ini digunakan siswa untuk memperbaiki atau memperbarui model-model yang dikontruksi; (5) Intertwining, siswa menggunakan keterkaitan antar konsep matematika untuk menyelesaikan masalah kontekstual.

Menurut Amiati (Umaedi, 2018: 98) kemampuan komunikasi matematis adalah suatu keterampilan penting dalam matematika yaitu kemampuan untuk mengekspresikan ide-ide matematika secara koheren kepada teman, guru, dan lainnya melalui bahasa lisan dan tulisan. Menurut permendiknas no. 22 tahun 2006 (Nofrianto, 2017: 114) standar isi pembelajaran matematika membahas tentang kemampuan mengomunikasikan gagasan melalui simbol, diagram, dan media untuk tujuan pembelajaran matematika.

Freudenthal dkk (2017), belajar matematika lebih menekankan siswa untuk menemukan sendiri konsep matematika dan memberikan permasalahan matematika untuk melibatkan keaktifan siswa dalam belajar. Proses matematisasi menurut Menurut Van den HeuvelPenhuizen (Nofrianto dkk, 2017:116) penggunaan gambar dan media dalam pembelajaran sangat membantu siswa dalam menginterpretasikan serta mengomunikasikan ide yang mereka miliki saat dihadapkan dalam permasalahan. 
Berdasarkan uraian permasalahan di atas, maka peneliti tertarik untuk melakukan suatu penelitian ilmiah yang bertujuan untuk mengetahui kemampuan komunikasi matematis siswa pada topik persamaan nilai mutlak linear satu variabel menggunakan pendekatan matematika realistik.

\section{METODE PENELITIAN}

Jenis penelitian yang digunakan pada penelitian ini adalah penelitian kualitatif. Peneliti mendesain pembelajaran untuk mendeskripsikan kemampuan komunikasi matematis menggunakan pendekatan matematika realistik pada soal kontekstual yang berkaitan dengan nilai mutlak linear satu variabel. Subjek penelitian adalah 2 siwa kelas X MIA SMAK St. Fransiskus Asisi Larantuka pada tahun ajaran 2019/2020. Pemilihan subjek penelitian berdasarkan kategori jawaban siswa, yaitu kemampuan siswa dalam menyampaikan situasi, gambar diagram, atau benda nyata dalam bahasa simbol, ide, atau model matematika, memaparkan penjelasan suatu ide, situasi, atau relasi matematika melalui gambar, menyelesaikan masalah matematika dengan rinci dan benar, memeriksa kembali jawaban.

Metode pengumpulan data berupa tes tertulis dan wawancara tidak terstruktur. Soal tes tertulis mengenai masalah kontekstual yang berkaitan dengan nilai mutlak linear satu variabel. Peneliti juga melakukan wawancara secara tidak terstruktur untuk mendeskripsikan kemampuan komunikasi matematis siswa dalam menyelesaikan masalah kontekstual yang diberikan oleh peneliti. Instrumen pengumpulan data berupa lembar jawaban tes tertulis yang memuat masalah kontekstual yang berkaitan dengan nilai mutlak linear satu variabel dan panduan wawancara secara garis besar mengenai kemampuan komunikasi matematis siswa. Artinya peneliti hanya menyediakan panduan wawancara secara garis besar dan pertanyaan yang berkembang sesuai dengan jawaban siswa dan informasi yang dibutuhkan oleh peneliti.

Teknik analisis data yang digunakan yaitu data reduction (reduksi data), data display (penyajian data), dan conclusion drawing verification (penarikan kesimpulan). Hasil pekerjaan dan wawancara siswa direduksi dan disajikan dalam bentuk kategori data berdasarkan langkah kemampuan komunikasi matematis yang sudah ditetapkan. Selanjutnya data akan dianalisis dan dibahas secara deskriptif kualitatif untuk menjawab rumusan masalah penelitian. 


\section{HASIL DAN PEMBAHASAN}

Peneliti melakukan pembelajaran di kelas X MIA sebanyak 2 pertemuan untuk membelajarkan materi persamaan nilai mutlak linear satu variabel dengan menggunakan pendekatan PMR. Peneliti membentuk 6 kelompok belajar dimana setiap kelompok terdiri dari 4-5 orang siswa yang dipilih secara acak. Di awal pembelajaran peneliti memberikan apersepsi kepada siswa mengenai materi persamaan nilai mutlak linear satu variabel. Selanjutnya, peneliti membagikan LKS kepada siswa yang berisi masalah kontekstual yang berkaitan dengan persamaan nilai mutlak linear satu variabel. Peneliti meminta siswa untuk memodelkan dan menyelesaikan masalah tersebut menggunakan cara masing-masing. Ketika ada siswa kesulitan dalam pembelajaran, maka peneliti memberikan topangan kepada siswa berupa pertanyaan yang bersifat memancing siswa untuk menemukan jawaban sendiri. Pada pembelajaran ini, siswa yang aktif sedangkan peneliti selaku guru sebatas fasilitator atau pendamping. Selesai mengerjakan soal, peneliti meminta setiap perwakilan kelompok untuk menyampaikan hasil diskusinya di depan kelas sedangkan kelompok yang lain memperhatikan. Jika ada jawaban antar kelompok berbeda, maka setiap siswa bebas memberikan pendapat untuk menyempurnakan jawaban temannya. Di akhir pembelajaran peneliti meminta siswa untuk menyimpulkan pembelajaran, kemudian disempurnakan oleh peneliti. Setelah dilakukan pembelajaran pada pertemuan pertama maka pada pertemuan kedua diadakan tes tertulis dan wawancara mengenai soal persamaan nilai mutlak linear satu variabel. Berikut adalah hasil pembahasan mengenai hasil tes dan wawancara siswa (S1 dan S2).

\section{Hasil analisis siswa 1 (S1)}

Menyatakan situasi, gambar, diagram, atau benda nyata ke dalam bahasa, simbol, ide, dan model matematika

Berdasarkan gambar 1, sebelum S1 menyelesaikan soal terlebih dahulu menulis yang diketahui dan ditanyakan pada soal serta membuat sketsa atau gambar ke dalam model matematika dengan menggunakan bahasa sendiri.

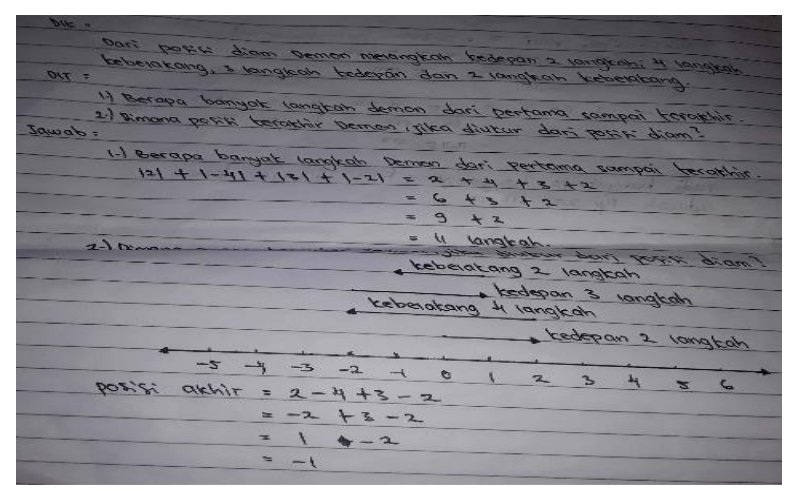

Gambar 1. S1 membuat gambar atau sketsa untuk menyatakan situasi dan ide-ide matematika 
Berikut adalah kutipan dari wawawncara S1.

P: apa yang diketahui dan ditanyakan pada soal?

S1: (siswa membaca soal)

P: dari soal atau masalah yang diberikan bagaimana ade membawa atau membuatnya dalam model matematika?

S1: pertama- tama saya membuat garis koordinat terus saya membuat sketsa berdasarkan garis koordinat

Berdasarkan LKS dan kutipan wawancara S1 sudah mampu untuk menyatakan situasi, gambar, diagram, atau benda nyata ke dalam bahasa, simbol, ide,dan model matematika.

\section{Menjelaskan suatu ide, situasi atau relasi matematika melalui gambar}

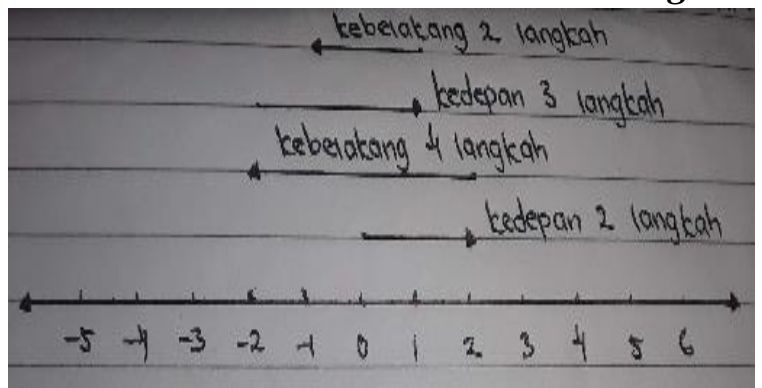

Gambar 2. S1 menjelaskan ide atau relasi matematika melalui gambar

Berdasarkan gambar 2, sebelum menjawab soal terlebih dahulu S1 membuat model matematika dengan menggunakan sketsa. Berikut ini kutipan wawancara S1.

$P$ : konsep atau strategi apa yang kamu gunakan untuk menyelesaikan masalah tersebut?

S1: konsep yang saya gunakan adalah terlebih dahulu saya gambar sketsa dan membuat anah panah dengan bantuan garis koordinat.

P: coba kamu jelaskan simbol anah panah yang kamu gunakan ini!

S1: kan anah panah ke kiri menjelaskan demon melangkah mundur dan anah panah kekanan menjelaskan demon melangkah maju.

Berdasarkan LKS dan kutipan wawancara S1 sudah mampu menjelaskan suatu situasi, ide,atau relasi matematika melalui gambar.

\section{Menyajikan solusi dari permasalahan matematika secara rinci dan benar}

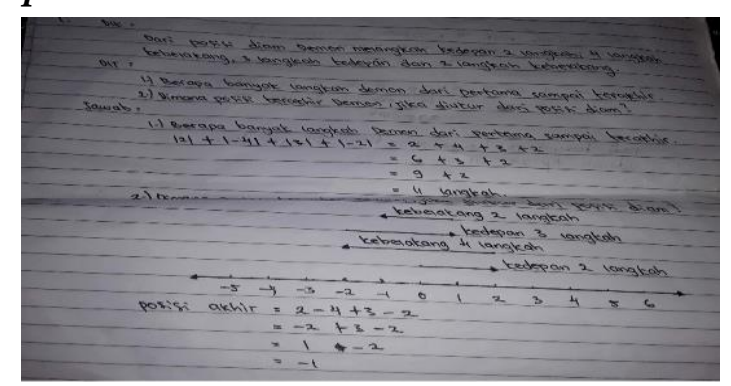

Gambar 3. S1 menyajikan solusi dari permasalahan matematika secara rinci dan benar 
Berdasarkan gambar 3, S1 sudah mampu untuk menyajikan solusi dari permasalahan matematika secara rinci dan benar.

\section{Melihat kembali jawaban}

Berikut ini adalah kutipan wawancara S1.

P: apakah kamu sudah yakin dengan jawaban yang kamu?

S1: ya. saya yakin karena tadi saya sudah periksa kembali jawaban saya dan ternyata benar. P: bagaimana jika ada teman yang jawabanya tidak sama dengan kamu?

S1: itu kan menurut dia. Saya tulis berdasarkan apa yang saya tahu dan saya yakin jawaban saya yang paling benar.

Berdasarkan kutipan wawancara S1 sudah memeriksa kembali jawabanya.

Berdasarkan hasil pekerjaan dan kutipan wawancara S1 dapat disimpulkan bahwa S1 sudah memiliki kemampuan komunikasi matematis dengan baik. S1 sudah mampu menyatakan situasi, gambar, diagram atau benda nyata ke dalam bahasa simbol, ide, atau model matematika, menjelaskan suatu ide, situasi atau relasi matematika melalui gambar, menyajikan solusi dari persamaan matematika secara rinci dan benar, memeriksa kembali jawaban siswa.

\section{Hasil Analisis siswa 2 (S2)}

Menyatakan situasi, gambar, diagram, atau benda nyata ke dalam bahasa, symbol, ide, dan model matematika

Berdasarkan gambar 4, sebelum S2 menyelesaikan soal terlebih dahulu S2 menuliskan apa yang diketahui dan ditanyakan pada soal serta membuat sketsa atau gambar kedalam model matematika dengan menggunakan bahasa sendiri.

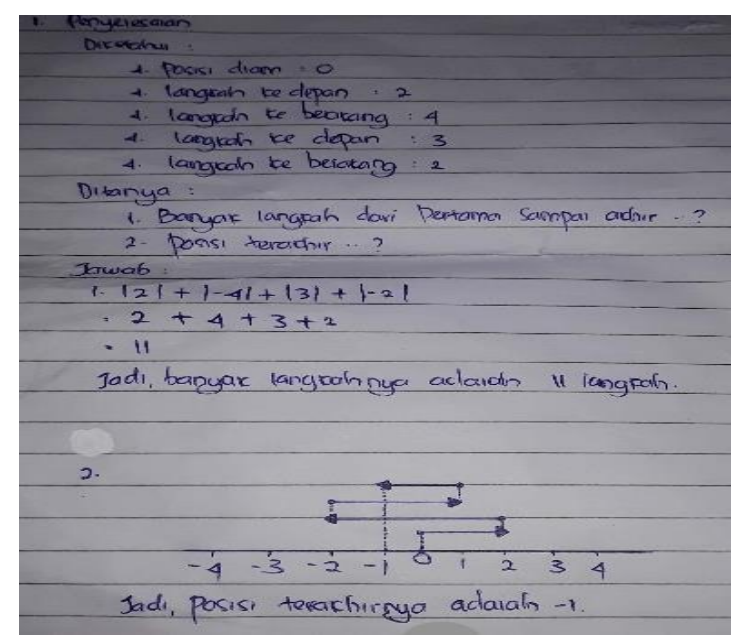

Gambar 4. S2 menyatakan situasi, gambar, atau benda nyata kedalam bahasa simbol, ide dan model matematika

Berikut ini adalah kutipan wawacara S2.

P: apa yang diketahui pada soal? 
S2:(siwa membaca pada soal).

P: setelah ade membaca soal tersebut bagaimana ade membawanya kedalam model matematika?

S2: pertama-tama saya membuat garis koordinat terus meletakan titik dan anak panah kemudian membuat sketsa.

Berdasarkan hasil pekerjaan dan kutipan wawancara S2, dapat disimpulkan bahwa S2 sudah mampu untuk menyatakan situasi, gambar, diagram, atau benda nyata ke dalam bahasa, simbol, ide,dan model matematika.

\section{Menjelaskan suatu ide, situasi,atau relasi matematika melalui gambar}

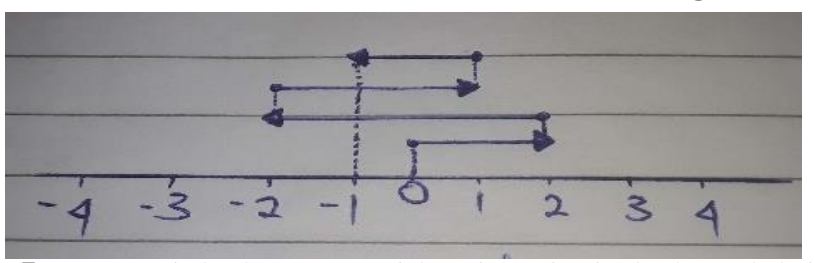

Gambar 5. S2 menjelaskan suatu ide, situasi, simbol, melalui gambar

Berdasarkan gambar 5, S2 sudah mampu menjelaskan suatu ide situasi atau masalah. Berikut ini kutipan wawancara S2.

P: konsep atau strategi apa yang kamu gunakan untuk menyelesaikan masalah tersebut?

S2:konsep atau strategis yang saya gunakan adalah saya harus membuat garis koordinat dan meletakan titik pada garis koordinat. Dan membuat anak panah.

P: coba kamu jelaskan gambar atau simbol yang kamu gunakan tersebut.

S2: begini kak, anak panah kekiri itu bearti demon melangkah mundur dan anak panah kekanan bearti demon melangkah maju.

Berdasarkan hasil pekerjaan dan kutipan wawancara S2, dapat disimpulkan bahwa S2 sudah mampu menjelaskan suatu situasi, ide atau relasi matematika melalui gambar.

\section{Menyajikan solusi dari permasalahan matematika secara rinci dan benar}

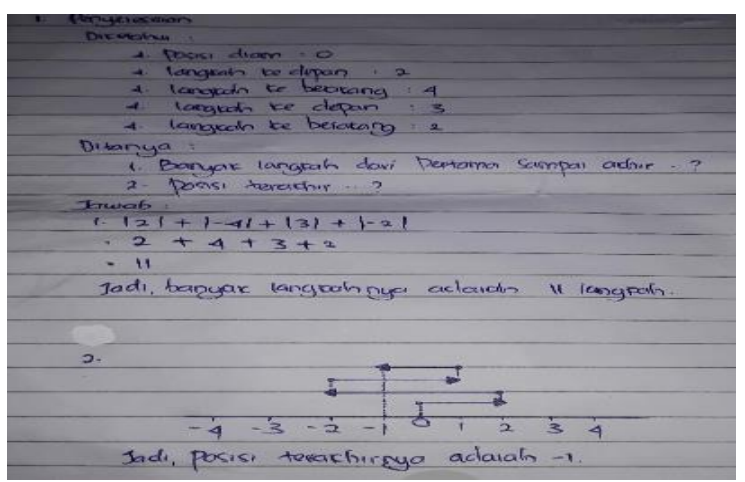

Gambar 6. S2 menyajikan solusi dari permasalahan matematika secara rinci dan benar 
Berdasarkan gambar 6, S2 sudah mampu untuk menyajikan solusi dari permasalahan matematika secara rinci dan benar.

\section{Melihat kembali jawaban}

Berikut ini adalah kutipan wawancara S2.

$P$ : apakah kamu sudah yakin dengan jawaban kamu?

S2: ya,,, saya yakin karena tadi saya sudah periksa kembali jawaban saya dan ternyata benar.

P: bagaimana jika ada teman yang jawabanya tidak sama dengan kamu?

S2: itu kan menurut dia. Saya tulis berdasarkan apa yang saya tahu dan saya yakin jawaban saya yang paling benar.

Berdasarkan kutipan wawancara S2 sudah memeriksa kembali jawabanya.

Berdasarkan hasil pekerjaan dan kutipan wawancara S2 dapat disimpulkan bahwa S2 sudah memiliki kemampuan komunikasi matematis dengan baik. S2 sudah mampu menyatakan situasi, gambar, diagram atau benda nyata ke dalam bahasa simbol, ide, atau model matematika, menjelaskan suatu ide, situasi atau relasi matematika melalui gambar, menyajikan solusi dari persamaan matematika secara rinci dan benar, memeriksa kembali jawaban siswa.

\section{SIMPULAN}

Berdasarkan hasil pekerjaan dan kutipan wawancara siswa (S1 dan S2) dapat disimpulkan bahwa, siswa sudah mampu memahami dan menyelesaikan masalah kontekstual yang berkaitan dengan materi persamaan nilai mutlak linear satu variabel yang diberikan dengan menggunakan pendekatan matematika realistik. Siswa sudah memiliki kemampuan komunikasi matematis dengan baik. Siswa mampu menyatakan situasi, gambar, diagram atau benda nyata ke dalam bahasa simbol, ide, atau model matematika, menjelaskan suatu ide, situasi atau relasi matematika melalui gambar, menyajikan solusi dari persamaan matematika secara rinci dan benar, memeriksa kembali jawaban siswa.

\section{DAFTAR PUSTAKA}

Umaedi, H. (2018). Meningkakan Kemampuan Komunikasi Matematis Siswa SMA Melalaui Pendekatan Pembelajaran Matematika Realistik. Pendidikan Matematika Raflesia. Vol. 3, No. 2, Hal. 94-106

Adri, N. dkk. (2017). Komunikasi Matematis Siswa Pengaruh Pendekatan Matematis Realistik. Gantang. Vol. 2, No. 2, Hal. 113-122.

Resi, B. B. F. \& Julie, H. (2018). Analysis of the problem solving ability of VIII-A student on linear equation system of two variables (LESTV), 5th ICRIEMS, Mei 2018, hal. 237-242. 
Resi, B. B. F. (2018). Analisis Kemampuan Pemecahan Masalah Siswa Menurut Langkah Polya Pada Materi Sistem Persamaan Linear Dua Variabel. Jurnal Edukreasi. Vol. 4, No. 1, Hal. $1-8$.

Suprihatiningsih, S., Sudibyo, N. A., \& Harmini, T. (2020). Eksperimentasi Mobile Learning Pada Mata Kuliah Kalkulus Integral Ditinjau Dari Kemampuan Bekerjasama. Buana Matematika: Jurnal Ilmiah Matematika Dan Pendidikan Matematika. https://doi.org/10.36456/buanamatematika.v10i1.2488 